\title{
Healing of the haemorrhaging woman as a model for checkmating stigma of people living with HIV
}

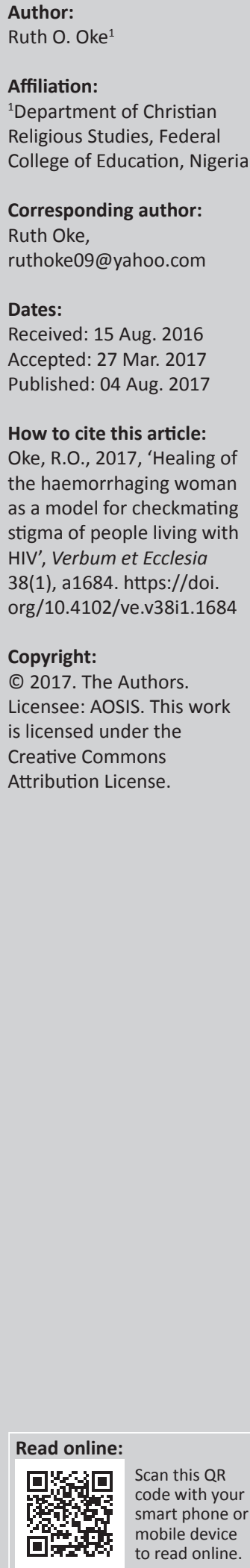

Diseases in human history are not just originating as a hit out of space. Some theologians contend that they must have originated with the human race. Apparently, it is inferred that they have come as a result of human disobedience to God in the Garden of Eden, or as a means of expression of his wrath. Other biblical perspectives ascribe disease to the work of the adversary or the Devil (Job 2:7), jealousy from others (Job 5:2) and self-indulgence (1 Sm 15:1-17, 16:14-15; 23, 1 Cor 10:1ff.). Stigmatisation of people with haemorrhaging condition (the issues of blood) in the biblical accounts of the old Jewish society compares well with stigmatisation of people living with HIV (PLH) in the current dispensation. It is needful to ask whether stigmatisation, discrimination and exclusion of the sick are a recent phenomenon. Landman observes that people with communicable diseases were separated from the rest of the congregation in the Old Testament dispensation. However, in the New Testament, a more charitable standpoint was anticipated because of the revolutionary stance of Jesus Christ in the Gospels. During his ministry, Jesus regarded the outcasts as integral members of the Jewish community. He in fact associated with and touched those who had dreadful diseases like leprosy (Mk 1:40-43, 2:1ff., Jn 8:1-9). Stigmatisation is associated with HIV in Nigeria and all over the world. However, the model of interaction set by Jesus with the Woman with the Issue of Blood in Mark's narrative in the Gospel proposed a charitable standpoint which if adopted by the Nigerian society will go a long way in stemming the stigma associated with HIV. It is anticipated that these biblical indices will facilitate reduction, if not the eradication of stigma in the society. The text under study will be contextualised.

Intradisciplinary and/or interdisciplinary implications: In this article, the African reading of the Bible is brought to the fore using a liberating theology of Jesus in the context of the haemorrhaging woman, using this as a standard in ameliorating the stigma experience of PLH in the era of HIV and AIDS in Nigeria context. It is applicable to all fields of biblical study, social sciences and even health practitioners.

\section{Introduction}

Diseases in human history are not just originating as a hit out of space. Some theologians contend that they must have originated with the human race (Pobee 1994:251; Heer 230-235). ${ }^{1}$ Apparently, it is inferred that they might have come as a result of human disobedience to God in the Garden of Eden, ${ }^{2}$ or as Davidson (1972:186) and Buttrick (1962:848) express as a means of expression of his wrath. However, the Bible established that the Lord is good and of gracious mercy, thereby disease in human planet cannot be as a result of his wrath (Is 51:6; Bibleinfo.com n.d.). Other biblical perspectives ascribe disease to the work of the adversary or the Devil (Job 2:7), jealousy from others (Job 5:2) and self-indulgence (1 Sm 15:1-17, 16:14-15; 23, 1 Cor 10:1ff.). The most distressful thing about some diseases is the accompanying stigmatisation and ostracism, which are exemplified in the subject of HIV and AIDS in current dispensation. It is needful to ask whether stigmatisation, discrimination and exclusion of the sick are a recent phenomenon. Landman (2004:267-300) observes that people with communicable diseases were separated from the rest of the congregation in the Old Testament (OT) times. However, in the New Testament, a more charitable standpoint was anticipated because of the revolutionary stance of Jesus Christ in the

\footnotetext{
1.The reason for this is the fact of the fall of man recorded in Genesis $3: 1-24$. The repercussion of the fall was the pronouncement made by God, which was believed to have inferred the inroad of illness as part of the thorn and thistle. Pobee explains that the age of science and technology have made an attempt to exorcise the supernatural, and reduce sickness to cause and effect.
}

2.See Genesis 3:1-12; Exodus 4:11; Deuteronomy 32:39.

Note: The abstract of this article was presented and accepted for the Society of Biblical Literature Annual General Meeting in 2015, at Atlanta, Georgia. I acknowledge the participant Grant offered to me by SBL to attend the 2015 Annual General Meeting https://ivbs.sblsite.org/meetings/Congresses_Abstracts.aspx?Meetingld=27 
Gospels. During his ministry, Jesus regarded the outcasts as integral members of the Jewish community. He in fact associated with and touched those who had dreadful diseases like leprosy (Mk 1:40-43, 2:1ff., Jn 8:1-9).

In contemporary society, Dube (2003:78-85) affirms the fact that HIV and its twin AIDS $^{3}$ are global monsters that stare at the world in the face, waking her up to the stack reality that the disease is endemic. The first diagnosed case of HIV was in the United States in the 80s, according to Rainey (n.d.) and WCC Publication (2001:10); however, it was unknown by the name HIV until 1985 and 1986, respectively when Dr Luc Montagner of Pasteur Institute in Paris and Dr Anthony Gallo of the National Cancer Institute Washington identified the virus causing HIV. But then the disease was erroneously believed to be the gay disease because it was first diagnosed among the gay and injected drug users (WCC Publication 2001). The World Health Organization (WHO 2013) survey estimates that 35 million people are living with HIV. In Nigeria, the pandemic was first diagnosed in 1986 in a 13 -year-old girl, and ever since the prevalent rate has risen from $1.85 \%$ in 1988 to $5.80 \%$ in 2001 . Since the time the pandemic was diagnosed, the Federal Ministry of Health has been carrying out yearly prevalent rating. The 2012 UNICEF (2015) survey estimated that there are 3.4 million adults living with AIDS in Nigeria and $50 \%$ of these are women. This ranked Nigeria as the second highest prevalence rate in Africa closely after South Africa (WHO 2013). In spite of this fact, the prevalence rate in states varies from one to another, with Abuja and Benue topping the list (CEDPA n.d.). ${ }^{4}$ The sad note on this is that the rate is rife among the age bracket of 20 and 29 compared with other groups. USAIDS (n.d.) survey decries the unfortunate situation because this age bracket constitutes the developmental age group that could affect the economy of any nation for good. It is of importance to note that total deaths of about 2.2 million have occurred through AIDS-related complications and diseases, among which 430000 were children less than 15 years in 2013, and about 220000 children who were orphaned by AIDS are living in Nigeria, as noted by WHO (2013).

Stigmatisation of people with haemorrhaging condition (the issues of blood) in the biblical accounts of the old Jewish society compares well with stigmatisation of people living with HIV and AIDS (PLH) in the current dispensation. The main purpose of this work is to fill a scholarly gap using biblical knowledge to solve the contemporary problem of HIV and AIDS and the stigmatisation of PLH. This study amplified Kinukawa (1994:4-5), the text under consideration through the refraction of triple focus lenses. The lenses are what the story implied during the Bible milieu from the original source carrier, the lens of the author and the lens of contemporary scholars. Secondly, the purpose of the research is to re-orientate the notion that the

3.In many advanced nations of the world, HIV has ceased to progress to become AIDS

4.It was noted that Abuja, closely followed by Benue, Akwa Ibom, Edo and some other Eastern States have the highest prevalent rate. Reason expounded for this fact was that Abuja is the capital city, where all sorts of immorality thrived, and Benue and that Abuja is the capital city, where all sorts of immorality thrived, and Benue and Benin because of some peculiar cultural practices such as wid
outlook of young women to wealth and riches and many more.
Bible and Jesus stories have cultural location, but are still applicable to contemporary situations. Stott (1997:74-75) believes that the Bible stories as much as they have cultural context unfolding the biblical years are still relevant and applicable to contemporary situations. Furthermore, it is to show the parallelism of the situation of the woman with the issue of blood $^{5}$ and that of the PLH in contemporary dispensation, as both attracts stigmatisation. Although, one may want to argue that haemorrhage is not a contagious condition like HIV, therefore, not synchronic! The fact that both health conditions are blood related categorises them as similar. Lastly, it is hoped that one can use Jesus' interaction with the WIB (Woman with the issue of blood) as a benchmark for what is expected of society and individuals with regard to relationship with PLH and their families. In view of these, it is hoped that this research will change people's orientation as regards associating with those infected and affected by the virus.

The scope of the research is the interpretation and comparison of the account of the experience of the WIB in Mark 5:25-34, with that of PLH. The WIB's narrative is interwoven with the story of the Jairus' daughter's healing in the same sequence of events. This text was preferred because it has a kind of similitude with HIV and AIDS in the modern times. In addition, Mark's narration of the account was given a pride of place because it is fuller and more vivid; this is one of the distinguishing characteristics of the Gospel of Mark (Akintunde 2004:40; Ayegboyin 2004:76). The interaction between Jesus and the woman was juxtaposed with that of the contemporary HIV ubiquitous situation to draw an inference.

\section{Background to impurity and stigmatisation in Old Testament biblical tradition}

The Life of the Jews is central to the commands and leading of Yahweh (Dt 28:1ff.). Apart from the Decalogue which forms the basis of Israelite relationship with God and fellow human, there are still other forms of code or law which have to do with the day-to-day life of the people. There are rules guiding relationships (see Leviticus 18 and 19), the kind and type of food for consumption and animals regarded as clean and fit for consumption (see Act 10:9-15a). In these instances are food items and animals referred to as kosher. ${ }^{6}$ This forbids the consumption of some other animals not sanctified by the ceremonial law and traditions of the Jews. The Israelite as a nation in the OT was guided by many rules and regulations in their day-to-day life and activities.

Beside this background of ceremonial laws or Purity Code, various ways abound in the OT by which an ailment or health condition could be described to connote the impression that it is beyond the ordinary. It is therefore a form of impurity for 5. Henceforth, wiB.

6.Kosher means clean or pure. Any animal or food tagged as Kosher is recommended and good for consumption to the Israelites. 
which a person can be stigmatised and isolated. The issue of blood is in this category and is discussed below.

\section{Child bearing, menstruation and abnormal flow of blood}

Kinukawa (1994:35) expounds that child bearing and menstruation and/or abnormal flow of blood are the two main causes of uncleanness in women in the OT dispensation. The reason for this is that it is only a woman that can have a flow of blood or menstruate according to her biological make-up. When a woman is having a flow of blood from the above conditions, she is seen as unclean and must not be found in the congregation of the people or in the open. Moyo (2004:131), quoting Douglas, espouses that proscriptive laws concerning menstruating women, women after childbirth and women with irregular blood issue are included among purity and impurity law in Leviticus. She clarifies that the Hebrew root word for menstruant niddah connotes 'set apart', 'cast out', 'banned', 'separated' and 'move away'. A woman with prolonging flow of blood is expected to dress herself in sackcloth and shout 'unclean, unclean' whenever she is venturing out from her seclusion. Guthrie and Motyer (1970:154) illuminate that after the blood flow must have ceased, she is required to observe a 7-day probation or verification of her cleansing, and the priests will have to make atonement for her before she could be integrated into the communal worship and living. There had been questions over the years by biblical scholars as to why menstrual and post-partum blood are regarded as rendering women unclean. Okunlola (2001:9-10) enlightens that anything declared unclean is unfit in the OT. She submits that for women to be declared unclean because of menstruation and post-partum blood is as a result of the lack of sophisticated means to handle such health conditions at that time.

In the book of Leviticus 12:1-8 after childbirth, a woman is seen as impure or unclean for certain days depending on the sex of the baby. If it is a male child, it is normally for 40 days and 80 days for a girl child. Throughout this time, she cannot participate in communal religious worship. Moyo (2004:131) postulates that the proviso seems to be typified by gender asymmetry; a man with seminal discharge is only unclean till evening time. The implication here is that the language of exclusion is more stringent on women. Kinukawa (1994:35) explains that not only does she feels degraded but she must also be responsible for and not to contaminate others. Belo's view (1981:41-44) is that she becomes untouchable throughout this period of impurity. She is separated from the pure in the spaces of the house and from everyday life. Conversely, Duro Adeleke during a personal interview on 20 May 2008 expressed that among the Yoruba, it is believed that anyone who has a flow of blood can render magical powers impotent and makes it inefficient. This is the reason why menstruating women are not allowed in the groove of some African gods or deities. In the traditional Yoruba setting, when a woman is menstruating or has just given birth to a baby, she cannot prepare some kind of meal because of the belief that the food will not be properly cooked. For instance, women in such condition cannot prepare bean meal known as moin-moin because it is believed that the flow will not make the moin-moin to solidify, which is a condition for it to be properly cooked for consumption. Such women are referred to as oni fu lara. ${ }^{7}$ They claim that she cannot partake in the worship of some Yoruba deities, for example, Oro cult, Egungun, Osun, Osugbo and so on (D. Adeleke [University of Ibadan] pers. comm., 20 May 2008). A menstruating woman in the groove of these deities is an abomination as menstruation is believed to contain a strong, vital force that can render powerful charms inactive and sacrifices unacceptable, was Okunlola's (2001:28) submission. Ayegboyin and Ishola (2013:98) postulate that even in some African indigenous churches, a menstruating woman is banned from the sanctuary.

In essence, the flow of blood as a result of child bearing and menstruation is termed impurity according to the ceremonial law of worship that pervades the OT era. She is perpetually segregated and cannot associate with others in the open (see Leviticus 15:13). This may have psychological effect on her because she is not allowed to interact with other members of her household or community. This could induce depression because of the isolation which also has health implications. For instance, among the Yoruba, there are cases of mental disorder in women who newly gave birth to children, which has defied medical and supernatural explanations. The condition is called abisinwin, meaning post-confinement madness. If women are prone to such disorder after childbirth, definitely it is obvious that post-parturition isolation will compound the situation.

\section{The woman with the issue of blood's healing and Jesus' interaction in Mark 5:25-34}

After the discussion about the background of the ceremonial laws that makes the woman unclean, it is expedient to turn the search light to the text under study. It is the story of the woman with haemorrhage or menstrual disorder. Pobee (2010:86) depicts this account as a story of suffering, pain and miserably draining illness coupled with untouchability. The Mark 5:25 thus reads from the Greek version of the New Testament:

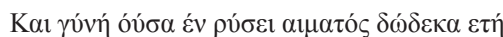

And there was a woman, who has had a flow of blood for twelve years. (Revised Standard Version [RSV])

The WIB's condition was presented to the reader as bleeding (from New International Version [NIV]) or having the flow of blood (in RSV), for 12 years. Muncherian presents two significant things about this woman's condition. Firstly, this woman had been haemorrhaging for 12 years. Literally, she had been experiencing her menstrual flow without interruption for 12 straight years. It is not difficult to imagine that she was anaemic and physically weak - debilitated by

7.A woman having a flow of blood. 
her physical sickness. Secondly, she was an outcast (Muncherian 2001). Leviticus 15 stipulates how she should be treated. She could neither approach the tabernacle nor enter the Temple, because she would defile it. So, she was prevented from being a part of the normal worship of her people ( $\mathrm{Lv}$ 15:25-30). For 12 years, this woman had lived painfully separated, ostracised and held at a distance by her family, her community and her religion. She was treated like an unclean, sinful outcast.

Baker adds that the exact nature of her problem is unknown and her existence was wretched because she was shunned by people. The biblical injunction of there is neither Greek nor Jew (Gl 3:28b) is not applicable to haemorrhagic condition and man-woman health issues. On the contrary, Barnes (1949) alludes to the fact that because of the woman's unclean nature, she was unwilling to make a personal application to Jesus as Jairus did or even touch his person. Giving the same view, Dorris (1975:127) explains this to be a wasting disease which had brought much suffering to the woman, thereby substantiating Muncherian (2001). Djomhoe (2005:133) articulates that the woman's description is short, which Kinukawa (1994:41) lends credence to by saying that the woman's name was not given, she is anonymous, a povertystricken woman with a desperate sickness. Her situation identifies her with no class or authority and Jairus, with whose daughter's healing her story was interpolated, was contrasted with her in terms of economic status, honour and even identity. Myer (1993:200) enunciates that Jairus was one of the rare-named persons in Mark's Gospel, who doubled as the head of his family and that of his social group as a ruler of the synagogue, taking into account this woman and Jairus' daughter's healing. It is quite obvious that the narration is biased, for the fact that there is no one without a name, however wretched the person may be. This is even a narration from an environment which took pride in name as the Africans.

Djomhoe (2005:133) offers that the text is silent on the details of the sickness, but gives information about its manifestation and about its multidimensional consequences. Ohnuki-Tieney (1994) writes that menstrual blood is a positive symbol of woman in the domestic domain, but taboo in the public domain. Above all, one discovers that the woman's problem is not just physical ailments, it is more complicated by the stigmatisation and isolation she experienced both in religious and social domains, which is the implication of her physical disorder.

In the Graeco-Roman era, Reynolds (n.d.) articulates that the concept of women's impurity was only one strike against female equality in ancient society. The other was that women were considered the property of men. Wijngaards (n.d.) says not only were women considered to be 'impure' during these periods but were also in danger of communicating their impurity to others. He further specifies quoting from Pliny the Elder, Natural History, book 28, chapter 23, that:

Contact with the monthly flux of women turns new wine sour makes crops wither, kills grafts, dries seeds in gardens, causes the fruit of trees to fall off, dims the bright surface of mirrors, dulls the edge of steel and the gleam of ivory, kills bees, rusts iron and bronze, and causes a horrible smell to fill the air. Dogs who taste the blood become mad, and their bite becomes poisonous as in rabies. The Dead Sea, thick with salt, cannot be drawn asunder except by a thread soaked in the poisonous fluid of the menstrous blood. A thread from an infected dress is sufficient. Linen touched by the woman while boiling and washing it in water, turns black. So magical is the power of women during their monthly periods that they say that hailstorms and whirlwinds are driven away if menstrual fluid is exposed to the flashes of lightning. (pp. 78-80)

Wijngaards (n.d.) unequivocally asserts that during the first five centuries of the Christian era, the Greek and Syriacspeaking part of the Church protected women against the worst effects of the menstruation taboo. The third century Didascalia explains that women are not unclean during their periods, and that they do not need ritual ablutions and their husbands should not abandon them. The Apostolic Constitutions repeated this reassuring message. In $601 \mathrm{AD}$, Pope Gregory I endorsed this approach. Menstruant women should not be kept out of church or away from Holy Communion. This was a more obliging stance than what operates in the OT milieu (Wijngaards n.d.).

Pilch (1985:142-150) interprets the WIB's condition from a biomedical perspective, perceiving disease as abnormality in the structure and or function of the organ system. It is a pathological state independent of whether or not it is culturally recognised. Pilch (1985:142-150) observes further that within the same culture the illness inevitably affects others, which includes the family, community and even the religious circle. Here, Kinukawa (1994:38) interjects that the healing must also involve the generality of the people, thereby providing a change of attitude towards the flow of blood and the WIB, which is a good example that Jesus epitomised in his interaction with her. In as much as this is pathological, there are other health conditions that could warrant bleeding in women. Holt (2007) classifies these to include chlamydia, fibroid tumour if they are located on the interior surface of the uterus and myopic pregnancy. Peters (Microsoft Encanta 2007) identifies others as ovarian cancer, stomach cancer and cancer of the colon. Thurston (1998:71) notes that the bleeding woman is marginalised on four counts: firstly, she is female; she is without a male relative to be her advocate, as she appears in the public without one; she is without financial resources as all her resources had been depleted by the physicians, and lastly, she was subject to blood taboo of the ceremonial law.

Commenting on the 12 years $(\eta \delta \omega \delta \varepsilon \kappa \alpha)$ of suffering, Harrington (2002:174) reiterates that it is a link to the story of Jairus' daughter who was incidentally 12 years too. He explains that the woman with virginal bleeding will die without bringing forth life because of her medical condition. So, also Jairus' daughter who at age 12 , the age of betrothal, is at the brink of death indicating her inability to bear children, and in essence could not contribute to the 
continuance of her community ${ }^{8}$ through the gift of life which primarily comes through woman. He asserts that in the two interwoven narratives, Jesus not only rescues them from death but also restores their life giving capacity, and both can now bring forth life from their bodies, one (the woman) racked by disease and the other (the dead girl) deprived of life itself (Harrington 2002:174). Brock (1988:83) enlightens that while the girl is getting to become a female, the woman was suffering from her femaleness. The 12 years also have political undertone as submitted by Dube (2003:126) and Dewey (1994:470-509).

Contemporaneously, the PLHs are encountering the same manner of treatment as the WIB from neighbours, colleagues and even family members. This inhuman treatment and ostracism are a great difficulty in the way of relationship and living with the virus from a positive acuity. Lawal interviewed on 28 December 2008 and Adeniran interviewed on 13 July 2007 confirmed that without the show of love, understanding, emphatic feeling and support, the use of antiretroviral drug will not help anyone living with the virus. They reiterate that the drugs are effective when the user is supported by love from all and sundry. The drug cannot do the magic of keeping the ill on good health, but the goodwill, care and support from people coupled with the drug can do wonders. These then accentuate the importance of support, care and love from others in the society to the PLH. These in turn make all to be their brother's keeper as enjoined in the scripture, (Gl 6:2). Verse 26 reads:

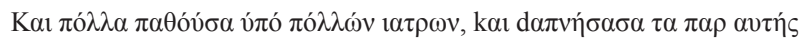

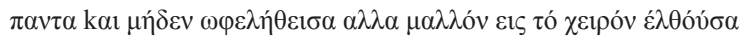

and who had suffered much under many physicians, and had spent all that she had, and was no better but rather grew worse. (RSV)

The text points to the fact that the WIB's search for healing and wholeness is indirectly her search for restoration of relationship with family, friends and the community of faith. Her search took her to the door of many physicians of her time, who duped, exploited and deprived her of all her resources without a commensurate cure for her malady. Marshal (n.d:27) comments that instead of a cure, they aggravate her pains and plight. Baker (1995:1501) clarifies that the Jewish Talmud preserves a record of such medicine and treatments prescribed for illnesses of this sort. Dr Lightfoot gives these as a sample, out of many others (Biblesoft 2003), also made mention remedies extracted from Bab. Shabb. fol. 110:

Rabbi Jochanan says: Take of gum Alexandria, of alum, and of crocus hortensis, the weight of a zuzee each; let them be bruised together, and given in wine to the woman that hath an issue of blood. But if this fails,

Take of Persian onions nine logs, boil them in wine, and give it to her to drink: and say, Arise from thy flux. But should this fails,

Set her in a place where two ways meet, and let her hold a cup of wine in her hand; and let somebody come behind and affright her, and say, Arise from thy flux. But should this do no good,

8.The continuity of a society depends on the ability to procreate. This is a common belief among the Jews and the Africans.
Take a handful of cummin and a handful of crocus, and a handful of faenu-greek; let these be boiled, and given her to drink, and say, Arise from thy flux. But should this also fails,

Dig seven trenches, and burn in them some cuttings of vines not yet circumcised (vines not four years old;) and let her take in her hand a cup of wine, and let her be led from this trench and set down over that; and let her be removed from that, and set down over another: and in each removal say unto her, Arise from thy flux? (Biblesoft 2003:n.p.)

The above prescriptions could be nothing more than superstitious and/or what the fourfold Gospel commentary called exorcism by charms (Biblesoft 2003). To cure such ailments, the physicians of Galilee at that time were not better than the medicine men of Africa! (Biblesoft 2003).

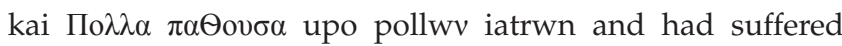
many things of many physicians, James, Fausset and Brown explain that the expression perhaps does not necessarily refer to the suffering she endured under medical treatment, but to the much varied treatment which she underwent as stated above (Biblesoft 2003). Harrington asserts that the double use of $\pi \mathrm{o} \lambda \lambda \alpha$ greatly and $\pi \mathrm{o} \lambda \lambda \omega \nu$ many magnifies her suffering (Harrington 2002:175). Going through the various prescription identified by the Talmud, it will definitely wear out any right-thinking person, not to mention one that is sick. The added advantage to discourage this treatment is that there is no assurance of a cure after the catalogue of herbs and activities. For the woman to be seen as suffered greatly is an understatement of what she experienced. She had come to her wits' end by the various deceit and treatment. This could be her reason for daring the consequences to try Jesus as her last resort and hope.

Verse 27 in Greek rendering reads thus:

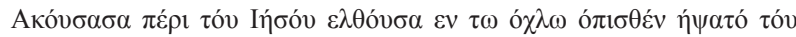

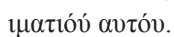

She had heard the reports about Jesus, (and) came up behind him in the crowd and touched his garment. (RSV)

The presentation of verse 27 from the Greek version has it that some ancient manuscripts differ in their record of the verse. $\pi \varepsilon \rho$ meaning 'of' or 'about' (literarily about concerning, with) was only found in $\aleph^{\mathrm{c}}$ in $\mathrm{A}, \mathrm{C}^{2}, \mathrm{D}, \mathrm{K}, \mathrm{L}, \mathrm{W}, \theta, \Pi, 0132^{\text {vid }}$, 0134, $\mathrm{f}^{1}, \mathrm{f}^{13}, 28,33,565,700$ 892, 1009, 1010, 1071, 1079, 1195, 1216, 1230, 1241 1242, 1253, 1365, 1646, 2148 and 2174, meaning that it is verified and authentic. In manuscript that has $\tau \alpha \pi \varepsilon \rho$ indicates it as a feminine article. This is used because the subject involved is a woman. This is only found in the following manuscript $\kappa^{*} B C^{*} \Delta 1546, \mathrm{t}^{33}$. However, Sherman's (1977:59) opinion is that where Matthew and Luke agreed against Mark, Mark is to be preferred.

Mark presented in verse 27 that the woman heard about Jesus, this implies that she still was in touch with the community that excommunicated and stigmatised her as a result of her ailment. Barclay (1981:130) comments that the woman came to Jesus as a last resort, having tried every other 
cure that the world could offer. This is a total transfer of attention from physicians to Jesus, making a complete turn with her emotions. She turned with her knowledge, which might be from previous feat of healing she heard Jesus performed. In addition, she circled her obeisance and her speech to Jesus was Robbins' (1987:502-515) observation on the verse. It is also possible to view this verse from the perspective of the fact that she decided to try Jesus after she was ruined; she had become poor and could no longer afford medical charges, Djomhoe affirms this assertion (2005:133). On the contrary, Walvoord and Zuck (1983:124) articulate that her hearing about Jesus' healing power aroused faith in her. Tasker (1969:101) substantiates Walvoord and Zuck's (1983:124) pronouncement, he utters that by acting on what she heard and coming to Jesus she showed a great faith not only in believing that Jesus could healed her but also in asking so little of him by being anonymous.

Comments from scholars about her coming from behind vary. Kinukawa (1994:41) declares sidetrack the law and avoid the knowledge that she had contaminated others and break the integrity of the holy community. Bruce's (1986:1163) opinion is that the embarrassment of her malady made her anxious to secure the healing she believed Jesus could impact without attracting any publicity, and was been modest, even for the ban placed on her life. Guthrie and Motyer (1970:157) confirm this by ascribing that she came from behind in order to avoid being noticed by anyone. Harrington's (2002:174) view is that the form of the verb used $\varepsilon \pi \iota \theta \theta \dot{\sigma} \sigma v$ from behind appears frequently in the regulation regarding bodily discharges, as specified in Leviticus. He ascribes that this is especially important for Mark who had earlier designated Jesus as the Holy One (Mk 1:24). As her impurity is highly contagious, she is expected not to touch any hallowed thing (Lv 12:4). To Okoroma, during Bible study on 16 August 2008, her stink made people to give her access to move closer to Jesus, showing how desperate she was. Frew expresses that in spite of the fact that she knew Jesus could heal her, she was afraid of her conscious unworthiness, thus illustrating the humility and confidence of a sinner coming to God for pardon and life (Frew 1949:349). Brock (1988:83) comments that the social structure of her time and place is a great bane on Jesus helping her if she were to come out in the front of Jesus. She compares this with Jairus' approach of coming to Jesus directly to seek help because of the culture that gives him honour, thereby honouring Jesus the same way.

Similarly, the story of HIV and AIDS follows the same trend in Nigeria. The PLH were seeking for help and healing at the onset of the pandemic, where help could not be obtained. They thought traditional medicine could offer healing and succour, which they earnestly desired, but alas! Most of the acclaimed healers were just dupes and fake hope-givers. Many, in the bid of looking for healing, lost all the resources they had like the WIB. Some lost their life because of stringent prescription of herbal remedies that are detrimental to health and well-being. Some could not come boldly to seek for counselling and treatment centres where help awaited them, till it was too late to assist. Thereby, many died when antiretroviral had been discovered to assist in stemming the spread of the virus in the blood stream. ${ }^{9}$ However, as the WIB took her destiny boldly in her hands and sought for help, so many had found hope in the face of hopelessness (Ecumenical Advocacy Alliance 2006). Many PLH have accepted the challenges of living positively with the virus and had turned counsellors to peers, the community and groups. With these actions, they have taken the bull by the horns, making bold where many homes and Christian communities have failed. These inadvertently have led many young ones astray by getting distorted information from peers and those who know little to nothing about the sensitiveness of the HIV and AIDS, sexuality and life. These PLH actions have posed a challenge to the individual, family, church, community, state and the nation at large. Tangible and laudable programme must be packaged, put in place and religiously followed to combat the effect and spread of the plague.

\section{The Greek rendering of verse 28 reads thus:}

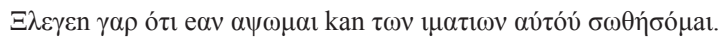

[If I touch even his garments, I shall be made well]. (RSV)

This verse was presented as a soliloquy of the WIB, connoting that it was her thought before it was acted out, 'If I touch even His garment I shall be made well'. Robbins' (1981:505) statement on Matthew's version of the same story utters that the repetition of the woman's thought which culminated into her action was a logical progression, which raised an expectation that was reliably fulfilled before the narrative ends. $\Xi \lambda \varepsilon \gamma \varepsilon$ for she said is an imperfect tense (Biblesoft 2003). The implication of this is that she might have kept saying as she pressed through the crowd, either to herself or to others. Robbins (1981:505) conveys that her contemplation was reported as direct, rather than indirect discourse. She clarifies this to be a special characteristic of Hebrew Bible narrative. Kinukawa (1994:41) affirms that her healing involves not only physical cure but also the recovery of her social and religious wholeness.

Feminist writers have been especially drawn to this story as a result of its peculiarity and the fact that it depicted the plight of a woman. Higgs (2007:n.p.) extols this account in Mark and the dexterity of the woman as a story of a woman who risked everything and was healed by her faith. Sales (2003:n.p.) portrays this miracle as an empowerment of women to break down the social-religious walls that restrained them, and even goes so far as to say that Jesus, in turn, needed something from the woman, because 'Jesus was also healed, and brought to a new wholeness'. Here, Sales' proposal is that Jesus became a boundary breaker. He was healed of the chauvinism of the Rabbi and religious leader of his time. In this manner, he championed a new course (Sales 2003). Taylor (1953:290) illuminates her touching Jesus' garment as a result of the fact that in early Christian Church, even handkerchief, apron and staff carried from healers were seen as an extension of the healers' personality. ${ }^{10}$

9.Mrs Faith Olawale, Faith Olawale's first wife and Joseph Bama's wife of The Gambia were some of the PLH who died before the introduction of antiretroviral drugs.

10.II King 4:18-29, Acts of Apostles 19:11. 
Critically examining the Markan narrative with the other two synoptists, Matthew and Luke, recorded that it was only the fringe of the garment that made contact; however, the fact of her touching cannot be erased (cf. Mt 9:20, Lk 8:44, Nm 15:38). Although the woman is aware that because of her condition, her touching Jesus will not only contaminate but as well bring him shame. Harrington (2002:175) strongly supports Woodward and Taylor that the healing through a touch was very common in the Hellenistic world, because healers were seen as figures of power. ${ }^{11}$ Jesus is seen as a Hellenistic $\Theta \varepsilon$ ió $\varsigma$ $\alpha v \eta \dot{\rho}$, a semi-divine figure gifted with supernatural power. Crysostom in Harrington notes that the woman was the first to approach Jesus in public based on the Gospel accounts, and that Jesus uses her faith to correct the lack of faith in the synagogue leader.

$\Gamma \alpha \rho$ for was explanatory as the narrator gives a within outlook of the woman's intention. This is known as soliloquising in modern literature and English language. It was her inner thought that was presented to the reader. Kinukawa enlightens that the phrase 'be made well' $\sigma \omega \theta \eta \dot{\sigma o ́} \mu$ is to be translated literally as be saved. From this is a link with PLH's attitude of status disclosure; those who had gone public about their status did not pay attention to the societal label of stigmatisation, ostracism, unclean, wayward, quarantine and had no right to live. They had summoned the courage to disclose their status in public glare. This takes bravery, willpower and a dare of the corollary. Harrington (2002:175) believes that the use of gap for in the narrative indicates the narrator's omniscient view of the woman's internal intentions. Such a view is called soliloquy in modern-

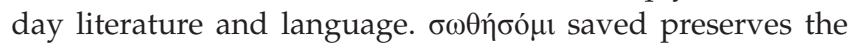
notion of rescue from illness and possible death. He observes that Mark uses this to highlight the linkage with surrounding narratives. Gingrich and Danker (1979:798) support this

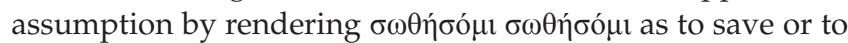
preserve or to rescue from natural danger and affliction:

Mark presented to us in verse 29 the validity of her faith in venturing to touch Jesus' garment.

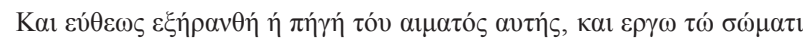

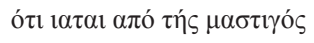

The verse above is translated thus:

And immediately the haemorrhage ceased; and she felt in her body that she was healed of her disease. (RSV)

Haemorrhaging condition as experienced by the woman could be a result of so many health conditions. Apart from fibroid which is primarily identified as triggering haemorrhage in women, there are other health conditions that could warrant flow of blood. Holt classifies these to include chlamydia, fibroid tumour if they are located on the interior surface of the uterus and myopic pregnancy (Holt 2007). Peters (Microsoft Encarta 2007) identifies others as ovarian cancer, stomach cancer and cancer of the colon, as well as chronic peptic ulcer. This faith (the WIB's faith), Guthrie and Motyer (1970:863) reflect, warrants instant cure and also vindicates her willpower for daring the laid down rule. Walvoord and Zuck (1983:125) assert that $\varepsilon \gamma v \omega$ she felt or she knew, this literarily means known experientially by a physical sensation in her body that she had been healed from her suffering. Aquino and McLemore clarify that she saw more in that touch than the disciples. They do not think it possible that Jesus could distinguish from a mere touch to that which was reaching out in faith (Aquino \& Lecmore 1993). The implication of this is that one would expect the insiders to know more about Jesus' power. It is amazing that the disciples did not, leaving the reader to desire more from them. Their lack of understanding of Jesus' ability is a minus on the long-standing relationship they had with Jesus. To Baker (1995:150), God graciously decided to heal her through that which was active in Jesus because it was God's wish definitely, Jesus must be in the knowing.

Guthrie and Motyer commenting on Jesus' inquisition in Mark 5 verse 30 to who touched him:



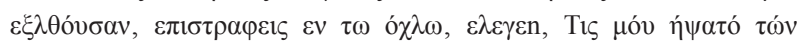

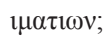

And Jesus, perceiving in himself that power had gone forth from him, immediately turned about in the crowd, and said, 'Who touched my garments'? (RSV)

Their opinion is that the question seems to have a twofold purpose firstly, he (Jesus) desired the information, for he was sure that power proceeding from him had gone forth in conscious response to the touch of faith. Secondly, he wished to elicit her open confession (Guthrie \& Mortyer 1970; cf. Rm 10:9-10). For with the mouth confession is made unto salvation ... Muncherian's (2001) idea about Jesus asking for who touched him is not that he is looking for her out of anger, or to expose this unclean woman to the ridicule of the crowd. He inserts that:

When Jesus asks, 'Who touched Me?' He is giving her an invitation. She has already been healed physically. Jesus could have left it at that. But there is a need here that goes deeper than any physical healing. Jesus gives an invitation to come and be healed inwardly- spiritually - of her deepest inward need - to know His love and the complete healing that He offers to each and everyone of us. (Muncherian 2001:n.p.)

Clifton (http:/ /www.//the7ones.com) declares that the fact that Jesus could discern such a touch among the many touches is a proof of his deity.

Barclay's (1981:132) remark is in the healing virtue that went forth from Jesus to heal the WIB; he emphasises that it costs Jesus something to heal the woman, and each time healing takes place through him. To him, this implies that whenever help is rendered to another, the giver has to be spent. In relation to the $\mathrm{PLH}$, the disclosure of status costs them freedom, free association and segregation as a result of the stigmatisation attached to such conditions in the society. Indirectly, this also affects whoever is associated with them like spouses, children and relatives. However, the society at 
large has no understanding that the disclosure of status couples with voluntary counselling and testing is in the best interest of all in the society. These will enable all concerned to garner strength to face and combat the pandemic, knowing fully well that people including our kith and kin, friends, colleagues and many more continually are being infected and affected by the pandemic. Like Jesus, they spent their freedom in divulging their status and this should be reciprocated in showing of love, affection, empathy and above all striving to get a cure. Everyone must become active to get rid our world of the pandemic. Furthermore, Barclay (1981:132) explains that the greatness of Jesus was his willingness to pay the price of helping others, which all must emulate and which the PLH who disclosed their status seem to be doing.

As Guthrie, Motyer and Barclay say, it can be alluded that Jesus only wanted her to confess to perfect her healing and to the praise and glory of God. Kinukawa (1994:43) making reference to Taylor says the phrase 'immediately the hemorrhage stopped and she felt in her body that she was

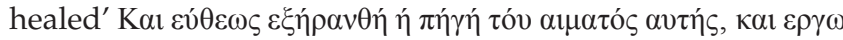

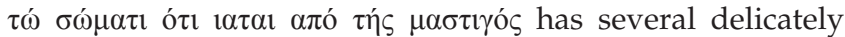
related points that should not be overlooked. Thus:

Her cure was immediate, the bleeding stopped as she touched Jesus; Mark or the tradition uses two aorist tense verbs $\varepsilon \xi \eta \dot{\eta} \rho \alpha \theta \dot{\eta}$ was dried up and $\varepsilon \gamma v \omega$ knew which indicate definite past happening and a perfect tense verb $1 \alpha \tau \alpha$ cured which is an abiding consequences. (Taylor 1953:291)

Kinukawa (1994:44) further explains that the healing caused a double effect on the woman and Jesus, which Myer cited in Kinukawa (1994:44) called a realisation of physical sensation in both the woman and Jesus. Kinukawa (1994:44) further clarifies that through this contact, the cultic order described in the Purity Law was overturned by the violation of the law by the woman, and then Jesus' power reversed the contamination into a cure. Thus, the myth of contamination by bleeding women was proven to be untrue. Consequently, here, Jesus broke the barrier that distinguished the clean from the unclean. Harrington (2002:175) ascribes to the fact that the woman's cure echoes Leviticus 12:7 where she is supposed to be pronounced cured by the priest after the purification rituals. This, he alludes, might be the reason why Jesus asked the question 'who touched me?'. He - the High Priest of the New Order (Heb 9:11) - wanted to certify her as clean as requested by the OT Purity Law, thus, affirming Jesus' claims that he came to fulfil the law and not to abort it (Mt 5:17). This is the greatest authorisation, better than that of the earthly High Priest. According to Harrington (2002:175), no ritual is involved here, but the power of Jesus that brings her soundness and completeness. The implication of this is that Jesus the High Priest of the New Covenant by his blood has certified her healed because the power that healed her went out of him. This indicates that the virtue from Jesus performed a double function - heals the woman and certifying her as cure which is the duty of the Priest. The affliction $\mu \alpha \sigma \tau i \gamma o$ s, literarily meaning scourge, echoes a similar use in Mark 3:10. (Harrington 2002:175) To Dorris (1975:129-130), Jesus felt and realised the particular time of transfer, because faith was involved in tapping into his power, where others touched and felt no healing influence, the power of faith got for her soundness because it was done in conviction.

Woodward (1986:63) clarifies that where King James Version

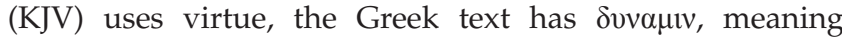
'power'. He testifies that the healing has nothing to do with Jesus' cloth, but from Divine Will of the Lord. To Walvoord and Zuck (1983:126), Jesus asked for who touched his garment in order to establish a personal relationship with the healed; in addition, they avow that Jesus being who he is knew at the instance the woman was healed and that power does not leave him without his will and knowledge, which they establish is consistent with his healing ministry.

Greek rendering of Mark 5:32 reads:

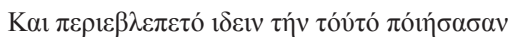

And He looked around to see who had done it. (RSV)

After Jesus' questions and the disciples' rebuff of him, Jesus looked around hoping to identify who touched him in faith. Coffman (n.d.) pronounces that Jesus was not looking for the person but for the woman who had done it. He by now knew not only the sex but also the history, the faith and the intention of the one who had already been consciously healed. Dorris (1975:132) further expatiates that the woman telling the truth revealed her heart, not in a secret whisper, but openly, because the Saviour wished her to make it a public property. She emphasises that the declaration of Jesus signifies continuous wholeness, a permanent possession of this gracious healing. Clifton concludes that it is more likely that Jesus was allowing the woman to identify herself, by drawing her out of the crowd (http://www.//the7ones.com). This could be likened to when God asked a similar question to Adam in the Garden of Eden (Gn 3:9), and yet his complete knowledge is not questioned. Bakers' (1502) opinion is that Jesus did not allow the woman to recede into the crowd as anonymous, as she would have wanted to be. In addition, he says that Jesus was willing to give a commendation of her faith and to assure her of permanent healing.

Harrington (2002:175-176) illuminates that the expression

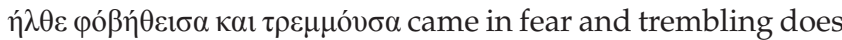
not denote a psychological disposition, but a reaction of human fragility in the presence of Divine Power. Fell before him ( $\left.\pi \rho \cos _{\varepsilon} \pi \varepsilon \varepsilon v \alpha v i \omega\right)$ has a slight verbal alteration, but is the same gesture as that of Jairus in 5:22, thus indicating another linkage between the two stories which Harrington explains as a posture of petition rather than worship. Stressing Jesus' response to the woman's declaration or confession, Harrington (2002:176) itemises this as fourfold: firstly, Jesus calling her $\theta$ v́ $\alpha \tau \varepsilon^{\rho} \rho$ 'daughter'. Secondly, a statement about her faith; thirdly, a dismissal in peace and, fourthly, a pronouncement that she is free from her affliction. Hargreaves upholds that Jesus treats her as a member of his family, and by extension a portion of God's family, which is the way he treats those who trusted him. However, he translated 'has 


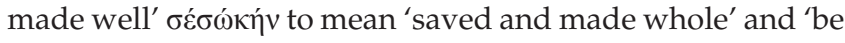
healed' as a means of Jesus sending her away with a blessing and with a promise that she would remain cured (Hargreaves 1995:99). The affectionate use of $\theta v \gamma \alpha \tau \varepsilon \rho$ 'daughter' shows a new relationship with Jesus. The insinuation of this is that Jesus sought her out in order to have a personal relationship and contact with her. Muncherian (2001) comments that it was the only time in the scripture Jesus addresses someone that way. Woodward (1986:64) corroborates that Jesus showed his feeling for her with the tender address $\theta v$ vo $\alpha \dot{\varepsilon} \rho$ 'daughter'. Newson and Ringe (1992:268) comment that addressing her as $\theta v \gamma \alpha \tau \varepsilon \rho$ 'daughter' by Jesus translates her under the protection of a new $\alpha \beta \beta \alpha$ father - Jesus, who is able

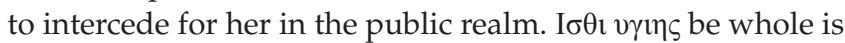
a continuous state of health and well-being for she was already cured $\alpha \pi$ o $\tau \eta \varsigma \mu \alpha \sigma \gamma \gamma \varsigma \varsigma$ $\sigma o v$ of her plague - her disease of scourge. He elucidates that a word from Jesus heals the moral malady of the sinner.

In summary, the encounter of the woman with Jesus is a beneficial one, as Kinukawa rightly expounds Jesus truly as a boundary breaker. What no rabbi (Rabbi) or religious leader of his time dares to do, he did and gave hope and life to the hopeless. In short, the fact that he expresses that he came to fulfil the law is very significant. If not for his compassionate interaction with people termed as outcast, sinners and many more, no one would have been able to understand the agony, depression, disgrace and many unpalatable experiences such experienced in the modern dispensation. There would have been precedence that the perpetuator of such discriminatory treatment would point to or cite as inference from the scripture. But thanks to the compassionate Lord who thought otherwise. Here, it could be inferred that the relationship Jesus had with the woman is appropriate and applicable to the HIV and AIDS circumstance of the modern dispensation. His Christology means that he is touched by the suffering of the PLH. He knows and feels with the entire world the brunt this pandemic is causing and confronting both the secular and the spiritual. As the Divine, he knows the suffering of the world. His Kingdom will arrive when the cure for HIV and AIDS is discovered, and when all concerns arise to the challenges of the pandemic. His mercy and love will be extended to the infected and affected of the scourge by all and sundry. A time will come when all, especially the faith community will be emphatic to all that are bearing the brunt of these plagues. Pertaining to ritualism, everyone contaminated by sin, diseases, shame and neglect of HIV and AIDS will find healing and acceptance in Jesus. As Garland (1996:220) affirms, faith enables anyone, regardless of advantages or disadvantages, to find healing and salvation in Jesus.

The story of the WIB and that of PLH is similar in characteristic because of the fact of stigmatisation and ostracism associated with the two instances. However, taking a critical appraisal at the text in the study, it revealed three major benchmarks or point of references which could serve as a pivot to hinge relationship with PLH in the modern dispensation, as exemplified by Jesus interacting with the WIB. The three premises are discussed below.

\section{Acceptance}

As discussed in previous chapters, the religious Purity Law of that time forbade the woman from coming out of seclusion, not to mention mingling and associating with others in the open. She cannot even appeal or speak to any male who is not a member of her family, unless fronted by a male family member. She is forbidden to interact with even the member of her immediate or extended family, but when Jesus took note of her after the healing was wrought, (Mk 5:28-31) he did not condemn her for coming in the press to snatch her healing from him. But rather he accepts her as a member of God's family and as a human being in need of God's love and affection. This is in contrast to the inhuman treatment which could have been meted to her by the religious leaders of that time and how they might have reacted. Mathew Henry (Phil 2006) comments that Jesus being desirous to see his patient asked, not in displeasure, as one affronted, but in tenderness, as one concerned, 'who touched my clothes?'. This view was corroborated by France (2002:105) and Hendriksen and Kistemaker (2001). Microsoft Encarta (2008) defines acceptance as coming to terms with something: the realisation of a fact or truth and the process of coming to terms with it. Wikipedia (2010) defines acceptance as having to deal with positive welcome, favour and endorsement in which, a person could like someone and have acquiescence for them because of their approval of that person. When Jesus discovered the woman after her healing, he came to term with the realisation of the fact that she is unclean. However, instead of rebuking her for daring to mingle with the crowd and daring to touch him, which has indirectly made him unclean and maintaining the status quo, he came to term and accepted her as someone to whom compassion should be shown and not otherwise. Coffman remarks that:

it is a matter of the utmost discernment and tenderness with regard to human sensibilities that Jesus had not required such an outpouring of the inmost secrets of her life while her pitiful condition still sat upon her; but, at a moment after she was fully restored to health, the Lord permitted the confession then. How beautiful: how tender, how so like Christ, and unlike men, is the tender regard of the Lord for this woman. Her condition was one with overtones of great sorrow. (Coffman n.d.:n.p.)

By this, Jesus violates the religious rule of that time, which Kinukawa termed overturning the cultic order of the Purity Law (Kinukawa 1994:44).

In the same vein, the PLH today in the society are clamouring for acceptance in spite of their sero-positive status. Acceptance typically contains the concept of approval, it is important to note that in the psycho spiritual use of the term, it infers nonjudgmental (Wikipedia 2010). The PLH yearn for nonjudgmental, favourable reception by the members of the society and the church. They desire that relationship prior to the disclosure of status be maintained and more should be developed. They desired that the society does not segregate, discriminate or preach the theology of $\sin ^{12}$ against them. But instead, compassion should be shown to them as depicted by Jesus in his relationship and interaction with the WIB.

12.Preaching the theology of sin means condemning the PLH by other members of the society or church community as being infected as a result of promiscuity. The reason for this is the fact that the main channel of transmission of HIV virus is through sexual contact. 
The WIB could be adjudged as having self-acceptance, which could be her rationalisation for coming among the crowd. Sometime people's estimation is that a woman's selfacceptance makes a person complacent. Self-acceptance leads to a new life with new possibilities. Some have this misconception that if you are happy with yourself, you would not change things about yourself. Wikipedia dictionary believes this is not true; one does not have to be unhappy with oneself to know and actively change things one does not like. However, it sums up that acceptance is always the first step in change that can also facilitate social acceptance (Wikipedia 2010). The clamour for approval and tolerance by the PLH is understandable and must be granted by all in order to assist them to live positively with the virus, and also contribute meaningfully to the development of the society. As Agbana, during an interview on 05 December 2009, rightly observed that once PLHs make themselves relevant to the society, then it will speak for them not minding their zero-positive status. The reason for this will be because they have what the society needs in order to function well and develop.

\section{Care}

Jesus cared for the WIB through the healing virtues that left him after her touch of faith. Muncherian (2001) broaches that Jesus is giving her an invitation after the healing. Although she has already been healed physically, he could have left it at that, but there is a need here that goes deeper than any physical healing. Jesus gives an invitation to come and be healed inwardly and spiritually of her deepest inward need, to know his love and the complete healing that he offers. This is an indication of his caring nature. For Coffman (http:// www.searchword.com), what depicted Jesus' show of care was resident in the fact that Jesus desired to bestow upon the woman a greater blessing than mere healing. He would not permit her, in a sense, to steal a blessing, but would provide it for her openly, and before all and, therefore, he asked for who touched him to come out openly. In the Women Bible Commentary (Westminster Philadelphia), the woman's action and fear was explained that Jesus would be angry with her and hence she did not want to identify herself. She believed that Jesus was able to cure people, but she did not know the strength of his love and care. This Jesus declared and it dissipates her fear. At this point, one could affirm that Jesus care did many things - he gave her life, sound and full health, hope and self-pride, which accorded her self-respect, social integration and association with the community of believers and even her immediate and extended family.

In contemporary understanding, caring could turn around hopeless situations. It is on record that delinquent persons have been known to mend their ways when care and affection were shown to them unconditionally. This is what Jesus did in this context. Her fearful disposition, trembling and partial healing were perfected by Jesus' compassionate disposition to her. In submission, such approach of care in situation of HIV and AIDS can bring significant change to PLHs outlook to life. It can give them hope, aspiration, comfort and confidence in spite of all odds.

\section{Inclusiveness}

Jesus refers to the WIB as daughter $\tau$ - $\gamma \alpha \tau \varepsilon \rho$. This is an intimate appellation; it implies that Jesus enthusiastically welcomed her into the family of God which he represents on earth. In addition to this, he conserved her healing by telling her to go in peace as her faith has made her whole. Scholars believed

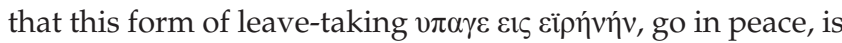
customary of Jewish tradition. James, Fausset and Brown (Phil 2006) believe her healing was a stolen one; therefore, Jesus' utterance for her to go in peace sets his royal seal of perfection upon it. The word 'daughter' in Nelson Bible Dictionary (Thomas Nelson Publishers 1986) is used in an even more general sense to refer to the female branch of a family or the female portion of a community. Here, the application is that Jesus called her a member of God's family of believers. She has become a joint heir with Jesus and thereby deserves the meat of the children - healing. Roberts (2004) affirms that:

it is true that the inclusiveness of Jesus was extraordinary. Unlike his religious contemporaries, Jesus included among his followers those who were generally excluded from religious life, if not polite society, people such as tax-collectors, 'sinners', lepers, and women. Yet, the inclusiveness of Jesus was not of the 'come as you are' sort. Jesus offered new, transformed life in the kingdom of God, not acceptance of all people as they were in their broken, sinful state. (n.p.)

The implication of this for the story of the WIB is that Jesus offered her transformation, life eternal in the Kingdom of his father and inclusiveness as a member of the faith community, which had eluded her during the course of her travail. Utley (http:/ / www.Biblesoftintl.com) comments that human being can become a family of God through faith in Jesus. Salvation, he expresses, is giving in birthing and legal terms, thereby indicating a family relationship. This is a Christian metaphor of what the WIB experienced.

In the era of HIV and AIDS, what the PLHs need is a stretch of the hand of fellowship and inclusiveness to them. They need the care as well as the compassion of the member of the faith community in particular and that of the larger society in general. As Jesus epitomised, the modern world should also be inclusive, valuing people for what they can offer and not stigmatised them because of their health condition or what in human rating is believed to be a misdeed. Jesus never segregates; he accepts all for who they were and offers ways of making them better by offering life. By this, the modern time Church should accept, care for and provide hope in a hopeless situation of HIV and preach the ultimate salvation of all mankind where all tears, sorrow, sickness and diseases will be no more ( $\operatorname{Rv} 21: 4)$, and where all will live without segregation, discrimination, nepotism, misogyny, racism, chauvinism and other forms of evil perpetuated by man as ideology. This is the clarion call from Jesus that in as much as you do this to one of my own you do it to me (Mt 25:40). This should be the watchword in the devastation of HIV and AIDS of the contemporary dispensation. 


\section{Conclusion}

In summary, the encounter of the woman with Jesus is a beneficial one as Kinukawa rightly expounds Jesus truly as a boundary breaker. What no rabbi or religious leader of his time dares to do he did and gave hope and life to the hopeless. In short, the fact that he expresses that he came to fulfil the Law is very significant. If not for his compassionate interaction with people termed as outcast, sinners and many more no one would have been able to understands the agony, depression, disgrace and many unpalatable experiences such will experience in the modern dispensation. There would have been precedence that the perpetuator of such discriminatory treatment would point to or cite as inference from the scripture. But thanks to the compassionate Lord who thought otherwise. Here it could be inferred that the relationship Jesus had with the woman is appropriate and applicable to the HIV and AIDS circumstance of the modern dispensation. His Christology means that he is touch by the suffering of the PLWHA. He knows and feels with the entire world the brunt this pandemic is causing and confronting both the secular and the spiritual. As the Divine, he knows the suffering of the world. His Kingdom will arrive when the cure for HIV and AIDS is discovered, and when all concerned arose to the challenges of the pandemic. His mercy and love will be extended to the infected and affected of the scourge by all and sundry. A time will come when all especially the Faith Community will be emphatic to all that are bearing the brunt of these plagues. Pertaining to ritualism, everyone contaminated by sin, diseases, shame and neglect of HIV and AIDS will find healing and acceptance in Jesus. As Garland ${ }^{13}$ affirms, faith enables anyone, regardless of advantages or disadvantages, to find healing and salvation in Jesus.

\section{Acknowledgements}

I acknowledge the Department of Religious Studies and the Postgraduate School, University of Ibadan, Ibadan; where the $\mathrm{PhD}$ thesis was examined. It is from this that this article was extracted. I also acknowledge the Board of Society of Biblical Literature, who provided me with a participant travel grant for the 2015 Annual General Meeting in Atlanta, Georgia, where this was presented at African Hermeneutic Panel session. The contributions from participants at the session have also enriched the article.

\section{Competing interests}

The author declares that she has no financial or personal relationships that may have inappropriately influenced her in writing this article. It was a research carried out by the writer for which she funded herself alone, as part of her contribution to knowledge and obtaining a Doctorate Degree of the University of Ibadan, Ibadan.

13.David E. Garland. 1996. Mark. New international version application commentary Grand Rapids: Michigan: Zondervan. 220.

\section{References}

Akintunde, D., 2004, The Gospels and the acts, African Association for the Study of Religion (AASR), Ibadan.

Aquino, F.A. \& McLemore, A.B., 1993, 'Markan characterization of women', in C.A. Osborn (ed.), Earliest Christianity, vol. 1, pp. 408-417, College Press, MO.

Ayegboyin, D., 2004, The synoptic: Introductory notes on the Gospels according to Matthew, Mark and Luke, Daystar Press, Ibadan.

Ayegboyin, D. \& Ishola, S.A., 2013, African indigenous churches: A historical perspectives, ACTS, Jos.

Baker, K., (Gen. ed.), 1995, The New international version study Bible, 10th anniversary edition, Zondervan, Grand Rapids, MI.

Barclay, W., 1981, The Gospel of Mark, daily Bible study series revised edition, The Saint Andrew Press, Edinburgh.

Barnes, A., 1949, St. Mark. Notes on New Testament explanatory and practical enlarge type edition, Baker, Grand Rapids, MI.

Belo, F., 1981, A materialistic reading of the Gospel of Mark, Orbis, New York.

Bibleinfo.com, n.d., Does God send killer hurricane and earthquakes? viewed 22 March 2017, from http://www.bibleinfo.com

Biblesoft Inc., 2003, Vincent's word studies in the New Testament, 2003, CD-ROM, Electronic Database. Copyright (C) 1997, All rights reserved, Seattle, WA

Brock, R.N., 1988, Journey to heart: A Christology of erotic power, Crossroad, New York.

Bruce, F.F., 1986, The International Bible commentary with new international version, Zondervan, Grand Rapids, MI.

Buttrick, G.A., 1962, 'Disease', in G. A. Buttrick (ed.), The interpreters dictionary of the Bible: An illustrated encyclopedia, vol 1, p. 848, Abigdon Press, Nashville, TN.

CEDPA, n.d., HIV prevalence in rural Benue State, viewed 08 January 2009, from http://www.CEDPA

Clifton, M.K., He called her daughter gods universal grace as revealed in Mark 5: 2534 , viewed 03 July 2010, from http://the7ones.com/2009/12/18/he-called-herdaughter-gods-universal-grace-as-revealed-in-mark-525-34/50710

Coffman, B., n.d., Coffman commentary of the New Testament, viewed 20 May 2010 from http://www.searchgodsword.org/com/bcc/view.cgi?bookmr\&chapter=005, http://www.searchgodsword.org/com/bcc/view.cgi?book=mr\&chapter=5\&verse= 25\#Mr5_25

Davidson, J.D., 1972, 'Disease' Davis dictionary of the Bible, fourth revised edition, Pickering \& Inglis Ltd., London, p. 186.

Dewey, J., 1994, 'The gospel of Mark', in E.S. Fiorenza (ed.), Searching the scriptures. A feminist commentary, vol. 2, pp. 470-509, Crossroad, New York.

Djomhoe, P., 2005, 'Gender and ethics in the fight against HIV/AIDS: A case study of Mark 5:25-34 an African context', in C. Klagba \& C.B. Peter (eds.), Into the sunshine integrating HIV/AIDS into the ethics curriculum, pp. 131-143, Zapf Chancery for EHAIA, Eldoret, Kenya.

Dorris, C.E.W., 1975, A commentary on the gospel according to Mark, Gospel Advocacy, Nashville, TN.

Dube, M., 2003, 'Talitha cum! calling the girl-child and women to life in the HIV/AIDS and globalization era', in I. Phiri, M. Dube \& M. Kanyoro (eds.), African women, HIV \& AIDS and the faith community, pp. 78-85, Cluster, Pietermaritzburg.

Ecumenical Advocacy Alliance, 2006, Keep the promise, a teaching resource on advocacy and HIV and AIDS, Ecumenical Advocacy Alliance, Geneva.

France, R.T., 2002, 'Mark', in I.H. Marshall \& D.A. Hagner (eds.), The new international Greek Testament, pp. 237-238, Eerdmans, Grand Rapids, MI.

Frew, R., 1949, Notes on New Testament explanatory and practical, enlarge type edition, Baker Books, Grand Rapids, MI.

Garland, D.E., 1996, Mark, new international version application commentary, Zondervan, Grand Rapids, MI.

Gingrich, F.W. \& Danker, F.W., 1979, A Greek-English lexicon of the New Testament \& other early literature based on Walter Bauer's augmented edition of 1958 University of Chicago Press, Chicago, IL.

Guthrie, D. \& Motyer, J.A. (eds.), 1970, The new Bible commentary, IVP, London.

Hargreaves, J., 1995, A guide to Mark gospel, SPCK, London.

Harrington, D.J., 2002, Sacra pagina, the Gospel of Mark, The Liturgical Press, Collegeville, MN.

Hendriksen, W. \& Kistemaker, S.J., 2001, Exposition of the Gospel according to Mark, New Testament commentary, vol. 10, Accompanying biblical Text is author's translation Baker Book House, Grand Rapids, MI, viewed 20 May 2010, from http://the7ones.com

Higgs, L.C., 2007, 'The woman who touched Jesus', Christianity Today, viewed 03 July 2009, from http://www.christianitytoday.com/tcw/2007/janfeb/14.14 html

Holt, L.H., 2006, Gynecology, Microsoft ${ }^{\circledR}$ Encarta $^{\circledR} 2007$ [DVD], Soft Copy: Microsoft Corporation, Redmond, WA, Microsoft ${ }^{\oplus}$ Encarta $^{\circledR} 2007$, (C) 1993-2006 Microsoft Corporation. All rights reserved.

Holt, L.H., 2007, 'Gynecology', Microsoft encarta Microsoft ${ }^{\circledR}$ Encarta ${ }^{\circledR} 2007$ No Pages, [DVD], Microsoft ${ }^{\circledast}$ Encarta $^{\circledR} 2007$, (c) 1993-2006.

Kinukawa, H., 1994, Women and Jesus in Mark: A Japanese Feminist perspective, Orbis Books, New York. 
Landman, C., 2004, 'The Bible as a source of healing and wellness for women affected by HIV/AIDS', in M.A. Oduyoye \& E. Amoah (eds.), The people of faith and the challenges of HIV/AIDS, pp. 267-300, Sefer Books for CIRCLE Publications, Ibadan.
chath

Linder, P., 2006, PowerBible CD, Linder Phil Online Publishing Incorporated, Bronson, MI.

Microsoft Encarta, 'Acceptance', Microsoft ${ }^{\circledR}$ Encarta ${ }^{\circledR} 2008 \subseteq 1993-2007$, Microsoft Corporation.

Moyo, F., 2004, 'Gendered stigma', in M.W. Dube (ed.), Africa praying, A handbook on HIV/AIDS sensitive sermon guidelines and liturgy, pp. 131-140, WCC, Geneva.

Muncherian, S., 2001. The touch Mark 5:25-34, viewed 23 August 2009, from http:// www.muncherian.com/s-mk5v25.html

Myer, C., 1993, Binding the strong men: A political reading of Mark's story of Jesus, Orbis, New York.

Newson, C.A. \& Ringe, S.H. (eds.), 1992, The women's Bible commentary, John Knox Press, Louisville, KY.

Ohnuki-Tieney, E., 1994, 'Illness and healing among Sakhlin Ainu: A symbolic interpretation quoted in $\mathrm{H}$. Kinukawa', in Women and Jesus in Mark, pp. 37-45, Orbis, New York.

Okunlola, A.O., 2001, 'Menstrual blood and priestly roles', in D.O. Akintunde (ed.) African women and the quest for women's right, pp. 27-35, Sefer Books, Ibadan.

Peters, K.R., 2006, Cancer-Medicine, Microsoft ${ }^{\circledR}$ Encarta ${ }^{\circledR} 2007$ [DVD], Microsoft Corporation, Redmond, WA, Microsoft ${ }^{\oplus}$ Encarta $^{\circledR} 2007$, (C) 1993-2006 Microsoft Corporation, All rights reserved.

Pilch, J., 1985, 'Healing in Mark a social science analysis', Biblical Theology Bulletin 14, 142-150. https://doi.org/10.1177/014610798501500404

Pobee, J.S., 1994, 'Healing an African Christian perspective', International Review of Mission LXXXIII(329), 251-261.

Pobee, J.S., 2010, 'HIV/AIDS in Africa: A Biblical perspective' in D. Ayegboyin, H. Agbanu \& E. Nihinlola (eds.), Globalization, technology, HIV\&AIDS and theological education in Africa, pp. 80-95, WAATI, Ibadan.

Rainey, L., n.d., Who discovered HIV. Gallo, Montagner or both? viewed 16 January 2009, from http://www.dallesvoice.com/artman/publish/article_2666

Reynolds, R., n.d., Woman's place in the world, viewed 26 June 2013, from http:// www.csus.edu/wac/journal/2013/Reynolds_Final_Draft.pdf

Robbins, V.K., 1981, 'The woman who touched Jesus garment', NTS: An International Journal 33(4), 505-515.

Robbins, V.K., 1987, 'The woman who touched Jesus garment: Socio-rhetorical analysis of the synoptic accounts', New Testament Studies 33, 502-515. https:// doi.org/10.1017/S002868850002097X
Roberts, M.D., 2004, The inclusiveness of Jesus Bible, viewed 28 December 2010, from http://www.markdroberts.com/htmfiles/resources/christianinclusiveness. htm\#sep1404

Sales, R., 2003, 'Somebody touched me', The Other Side, November and December 12 viewed 03 July 2009, from http://the7ones.com/2009/12/18/

Sherman, E.J., 1977, The Gospel according to Saint Mark, Adams and Charles Black, London.

Stott, J.R.W., 1997, The message of Timothy and Titus, The Bible Speaks Today Series, Inter Varsity Press, Leicester.

Tasker, R.V.G., 1969, Mark: An introduction and commentary by Alan Cole, Tyndale, London.

Taylor, V., 1953, The Gospel according to Mark, Macmillan, London.

Thomas Nelson, 1986, Nelson's Illustrated Bible Dictionary, Copyright (C 1986, Thomas Nelson Publishers. Soft Copy, BibleSoft CD, Seattle, WA.

Thurston, B., 1998, The women in the New Testament: Questions and commentary, Crossroad, New York.

UNICEF, 2015, Nigeria at a glance, viewed 09 March 2015, from http://www.unicef. org/infobycountry/nigeria

USAIDS, n.d., Nigeria country profile on HIV/AIDS, viewed 08 May 2009, from http:// www.usaids.gov/locations/sub-sahara_Africancountries/Nigeria

Utley, B., The NASB (update) study Bible New Testament supplement, viewed 26 December 2010, from http://www.biblesoftintl.com

Walvoord, J.F. \& Zuck, R.B., 1983, The Bible knowledge commentary: An exposition of the scripture by Dallas seminary faculty based on New Testament version, Victor Books, Wheaton, IL.

WCC Publication, 2001, Facing AIDS: The challenge and the churches response, WCC Publications, Geneva.

WHO, 2013, Global summary of the HIV/AIDS epidemic, viewed 04 March 2015, from http://www.who.int/hiv/data/en

Wijngaards, J., n.d., Women were considered ritually unclean, viewed 26 June 2013, from http://www.womenpriests.org/traditio/unclean.asp

Wikipedia Online Dictionary, Acceptance, viewed 21 May 2010, from http://en. wikipedia.org/wiki/Acceptance\#Definition

Women Bible Commentary, Ethnicity and legal considerations in the WIB's story Mark 5:25-34, The Women's Bible Commentary, Westminster, Philadelphia, PA viewed 20 May 2010, from http://findarticles.com/p/articles/mi_mOLAL/is_3_34/ ai_n6260526/pg_10/

Woodward, R.R., 1986, A commentary on Mark, vol. 2, ACU Bookstore, Abilere. 